\title{
Władza i to, co politycznie nieokreślone: niewczesne rozważania o dekonstrukcji
}

\section{Power and That which is Politically Indefinable: The Untimely \\ Meditations about Deconstruction}

\begin{abstract}
The aim of this paper is to reconstruct political thought contained in the so-called French theory, associated with postmodernism and known as post-structuralism and deconstruction. The theory had to provide answers to questions like, what is the cause of inequalities and injustices in democracy? How is scientific knowledge generated by public research institutions like universities involved in the creation of these inequalities and injustices? What is the phenomenon of power and submission in the case of free people who live in a state which should safeguard their human and civil rights? This paper consists of preliminary comments and six main parts. Part one describes social and political context in which postmodernism arises. Part two deals with French theory. Part three relates to deconstructive political theory and its research method. Part four is about violence and seduction as forms of power exercised also by its theorists themselves. Part five deals with both politics and power reduced to legal order. Part six, the last one, is about justice understood as utopian pulses contained within theory - it includes the conclusions of deconstructive political analysis.
\end{abstract}

Keywords: French theory, deconstructive political theory, power, violence, seduction, justice

„Przestańcie czynić nieprawości! Uczcie się pełnić dobre uczynki, szukajcie tego, co sprawiedliwe!

Poskromcie ciemięzcę! Prawo przyznajcie sierotom i wdowy bierzcie w obronę!" 


\section{Uwagi wstępne}

Niewczesne - to tyle, co w niewłaściwym czasie, anachroniczne. Termin sam w sobie już dziś przestarzały, wyraźne zapożyczenie z klasycznego tłumaczenia Leopolda Staffa Nietzscheańskich Niewczesnych rozważań - Unzeitgemäße Betrachtungen (1874). Skojarzenie nieprzypadkowe - przynajmniej z dwóch powodów. Po pierwsze dlatego, że powiązane jest w tytule z dekonstrukcją, pojętą jako stanowisko filozoficzne, silnie inspirowane myślą tego niemieckiego filozofa, i nierozłącznie związane z pewną strategią polityczną i intelektualną. Wiedza na jego temat znajduje się już dziś w podręcznikach z filozofii najnowszej. Niewiele nowego da się więc o nim powiedzieć. Istnieje jednak i drugi powód, znacznie ważniejszy z uwagi na tytułową władzę. Wyjaśniam: Nietzsche kończy swoje rozważania w stylu może nazbyt egzaltowanym, jak na wrażliwość dzisiejszego, ponowoczesnego czytelnika, niemniej jednak merytorycznie trafnym, a jak historia pokaże - także i proroczym. Powiada mianowicie, że ważniejsza od państwa i jego instytucji - zwłaszcza uniwersytetów - jest „egzystencja filozofii na ziemi”, że w niej cały ratunek na przetrwanie w nowoczesnym świecie: „W miarę jak wzmaga się niewola w jarzmie opinii publicznych i niebezpieczeństwo wolności, może rość godność filozofii” (Nietzsche, 1912, s. 305) - jak brzmią jego słowa we wspomnianym tłumaczeniu.

Otóż francuskim filozofom, nazwanym w Ameryce poststrukturalistami, takim jak Michel Foucault czy Jacques Derrida, w niecałe sto lat później przychodzi znaleźć się w tej samej paradoksalnej sytuacji ujarzmionych w wolności. Ówczesna Francja, mimo gospodarczych sukcesów, przeżywa narastający kryzys społeczny i polityczny, który kulminuje w majowej rewolucji 1968 roku. Miała ona odrzucić stary świat z jego hierarchicznymi podziałami i nierównościami społecznymi, faworyzowaniem uprzywilejowanych klas. Sytuacja absurdalna do potęgi - uczeni muszą zadać sobie pytanie, jak mogło dojść do tego we Francji, kolebce demokracji, niezłomnej głosicielce idei wolności, równości i braterstwa? Ale to nie wszystko - nieuchronnie muszą też oni rozliczyć się z własną tożsamością, stawić czoła ówczesnej nauce i zapytać ją, co ważnego ma ona do powiedzenia w sprawie problemów współczesnego społeczeństwa, które przeżywa konflikty i domaga się zasadniczych reform. Dominujący wówczas - także w naukach politycznych - funkcjonalizm (Talcott Parsons, Robert K. Merton i in.) był mało atrakcyjny pod tym względem. Konkretną rzeczywistość społeczną przesłaniał on abstrakcyjną siatką pojęciową - stosowaną do wszystkich społeczeństw bez różnicy. Operował pojęciem systemu jako narzędziem analitycznym służącym do badania ładu społecznego, czyli całokształtu wzajemnych oddziaływań aktorów społecznych. System jest nastawiony na samoutrzymywanie się: ma spełniać funkcję adaptacyjną - dostosować się - dzięki ekonomii - do otoczenia, osiągać - dzięki polityce - wyznaczone sobie cele, integrować wspólnotę dzięki autorytetom i wreszcie pielęgnować - dzięki kulturze - własne wzory 
działania. Ta hipernowoczesna opowieść, promująca postawy konformistyczne, dążące do zachowania ładu społecznego, nie tylko mogła przerażać swoją abstrakcyjnością wobec problemów trapiących zachodni świat w latach 60. Mogła być też postrzegana jako nauka w służbie ideologii - narzędzie do utrzymania istniejących struktur społecznych, hierarchii bogactwa i władzy. Podkopujące wiarę w potrzebę i możliwość rozwiązywania nowych konfliktów i kryzysów, ulepszeń i zmian systemu demokratycznego.

Trudno się dziwić, że w tych warunkach rodzi się ruch oporu. Powstają intelektualne manifesty i barykady, na których - kazus Alaina Touraine’a - wygłasza się takie oto hasła programowe:

Myślę jednak, że nadszedł czas, by rozwinąć naukę społeczną ze wszystkimi specyficznymi dla niej treściami, choć powinna ona zajmować miejsce w obrębie nauk przyrodniczych. Społeczeństwo jest systemem, odmiennym jednak od innych ze względu na swoją historyczność, zdolność wytwarzania samego siebie. Jednym z najpilniejszych być może zadań socjologii jest objaśnienie wielkiej przemiany, jaką przeżywamy, opisanie nowych orientacji kulturowych, ale także pierwszych postaci sprzeciwu wobec technokratycznej kontroli nad zmianą oraz reakcji na instytucjonalny i organizacyjny kryzys towarzyszący głębokim zmianom (Tourain, 2010, s. 285) [po francusku 1974].

Trudno też dziwić się i temu, że w omawianym czasie na gruncie francuskiej humanistyki niezwykłym powodzeniem cieszy się psychoanaliza, postrzegająca kulturę i społeczeństwo przede wszystkim jako siłę represyjną w stosunku do pragnień jednostki. Tu z kolei za przykład może posłużyć Jacques Lacan, psychiatra i psychoanalityk, uznany za najwybitniejszego kontynuatora Freuda. Jego seminaria, prowadzone od początku lat 50. przez prawie trzy dekady, miały ogromne oddziaływanie, można odnieść wrażenie, że formowały one wręcz całe pokolenia francuskich intelektualistów.

Tak czy inaczej, na barkach wspomnianych filozofów spoczywa powinność poradzenia sobie $\mathrm{z}$ obydwiema powyższymi sytuacjami problemowymi - społecznymi i naukowymi. Muszą odpowiedzieć przynajmniej na następujące pytania: Skąd biorą się nierówności i niesprawiedliwości w demokracji? I jaki jest udział w ich tworzeniu wiedzy naukowej, powstającej w ramach państwowych instytucji takich jak uniwersytety? Na czym polega fenomen władzy, relacji podległości w sytuacji, gdy chodzi o wolnych ludzi w państwie, które ma stać na straży ich praw jako obywateli i ludzi w ogóle? Z doktrynalnego, formalnoprawnego punktu widzenia zdaje się więc to problem bezprzedmiotowy. Ale rzeczywistość mówi zgoła coś innego - o ujarzmionej przez państwo i społeczeństwo wolności. Żeby móc w niej nadal żyć i nie zrezygnować z ideałów emancypacyjnych, trzeba odwołać się do filozofii - teorii. Nietzsche musiał mieć zatem rację.

Zaczynam od opisania kontekstu społeczno-politycznego, w którym pojawia się postmodernizm - nowy paradygmat w naukach społecznych i humanistycz- 
nych. W jego ramach zaś mieści się - o czym w części drugiej - tzw. teoria francuska, związana z postmodernizmem i znana jako poststrukturalizm lub dekonstrukcja. Czym jest dekonstrukcyjna teoria polityki i na czym polega stosowana przez nią metoda badań - o tym piszę w części trzeciej. O przemocy i uwodzeniu jako formach władzy sprawowanej także przez samych jej teoretyków - w części czwartej. O polityce i władzy zredukowanej do systemu prawnego opowiada część piąta. Wreszcie, na finał, o sprawiedliwości jako utopijnych impulsach w teorii - wnioski z dekonstrukcyjnej analizy polityki.

\section{Postmodernizm, zimna wojna i liberalizm}

Lata 60. i 70. XX wieku to dekady szczególnie ważne, chciałoby się nawet powiedzieć: przełomowe dla teorii polityki - zresztą nie tylko dla niej, w ogóle dla nauk społecznych i humanistycznych. Na podstawie dzisiejszego stanu wiedzy $\mathrm{z}$ teorii i historii nauki słowo „przełom” jest tu niewątpliwie pewnym nadużyciem, ale perswazyjnie jakoś samo się narzuca. Pojawiają się bowiem wówczas po raz pierwszy słowa zaklęcia, które nieprzerwanie będą powtarzane we wszystkich odmianach do końca stulecia, a właściwie do przełomu (sic!) stuleci - a i do dziś chyba nie straciły całkowicie swojego uroku: postmodernizm, (społeczeństwo) informacyjne, postindustrialne i ponowoczesne. Dla teorii oznaczają one zmianę paradygmatów, przejście od formuły badań dyscyplinarnych do interdyscyplinarnych. Te pierwsze są ze swej genezy oświeceniowe, oparte na założeniu o racjonalności świata i poznawalności jego reguł, dla każdej dyscypliny przedmiotowej innych, chociaż zbieżnych co do wspólnych tendencji rozwojowych i postępowych. Te drugie, interdyscyplinarne, mają zaakceptować złożony, pluralistyczny i heterogeniczny charakter (zwłaszcza) zjawisk społecznych oraz sposobu ich badań, transwersalnych (etymologicznie: od łac. trans - przez, poprzez; a więc: poprzecznych, skrzyżowanych), przemieszczających się na pograniczu i pomiędzy różnymi dyscyplinami - typami i formami racjonalności. Wszystko to dzieje się w czasie zimnej wojny, w którym nadal jeszcze, siłą historycznych koincydencji, niepodzielnie rządzą dwie wielkie narracje, nowoczesne ideologiczne abstrakcyjne opowieści o kapitalizmie i komunizmie, o wolnym rynku i centralistycznie zarządzanej gospodarce, realizującej koncepcję państwa dobrobytu. Postmodernistyczna teoria obnaża iluzoryczność obydwu - a i praktyka nie pozostaje w tyle, ona także daje do zrozumienia, że dalej nie da się już utrzymywać przy życiu tego duopolu fikcyjnych konstrukcji, represyjnych wobec rzeczywistości.

Sytuacja dość zagmatwana i paradoksalna. Czas współistnienia i ścierania się na różnych poziomach i w różnych wymiarach zjawisk i procesów kontynuacji oświeceniowych projektów naukowych i społecznych oraz ich demistyfika- 
cji. O tych ostatnich jeszcze za chwilę. Zatrzymajmy się nad pierwszymi. Nadal na topie są wówczas idee liberalne - docierające na Zachód relacje ze stanu gospodarki Związku Radzieckiego i całego obozu państw socjalistycznych stanowią na tyle mocny argument, żeby przekonać większość na rzecz idei wolności, utożsamionej z wolnym rynkiem. Przypomnę, nie zagłębiając się w szczegóły, że powojenna Europa bynajmniej nie jednoczyła się wokół jakichś enigmatycznych „wartości europejskich”, o których dzisiaj głośno się mówi (chociaż nadal otwarte pozostaje pytanie, czym one miałyby właściwie być), ponieważ takie wówczas nie istniały, a w każdym razie, jeśli nawet wedle niektórych istniały, to w powszechnym przekonaniu utraciły one swoją moc obowiązywania i zdolność do integrowania społeczeństw i państw, których elity brały udział nie tylko w chwalebnych czynach II wojny światowej, lecz także - nieraz - w jej zbrodniach (wystarczy przyjrzeć się historii rozliczeń z nazizmem w Republice Federalnej Niemiec). Jedyne, co wobec tego pozostało, to rachunek ekonomiczny. Pierwsze stadia integracji to Europejska Wspólnota Węgla i Stali (1952 r.) oraz Europejska Wspólnota Gospodarcza (1958 r.), która utrzymała się do końca porządku jałtańskiego.

Wracam do liberalizmu. Triumfuje on w najlepsze zarówno $\mathrm{w}$ teorii - potwierdzonej ekonomicznymi Nagrodami Nobla dla Friedricha Hayeka (1974 r.) i Miltona Friedmana (1976 r.) - jak i w praktyce politycznej, kojarzonej z rządami Margaret Thatcher i Ronalda Reagana. W dziewiętnastowiecznym projekcie liberalnym funkcją państwa było utrzymywanie prawa i porządku oraz angażowanie w „prace publiczne”, w neoliberalnym zamyśle dwudziestowiecznym - jak w latach 50. tłumaczy Friedman - ma ono ponadto spełniać funkcję regulowania ram niezbędnych do rozwoju swobodnej konkurencji i efektywnego działania polityki cenowej. „Pociąga to za sobą - pisze amerykański ekonomista - dwa główne zadania: po pierwsze, ochrona wolności do zakładania przedsiębiorstw w każdej dziedzinie, wchodzenia do dowolnego zawodu i wykonywania go; po drugie, świadczenie stabilności monetarnej" (Friedman, 1951, s. 3). Neoliberalizm w wersji niemieckiej, znany jako ordoliberalizm tzw. szkoły fryburskiej w ekonomii, w pewnym stopniu realizował już w latach 50. i 60. Ludwig Erhard, najpierw jako minister gospodarki w rządzie Konrada Adenauera, a następnie jako kanclerz. Ordoliberałowie nie byli klasycznymi liberałami, promowali bowiem społeczną gospodarkę rynkową, specyficzną wersję liberalnej gospodarki kapitalistycznej, łączącej idee wolności gospodarczej i prywatnej własności z ideą „ładu społecznego”. W kształtowaniu tego ładu ma brać udział państwo poprzez wyrównywanie szans w konkurencji rynkowej, promowanie dobra ogółu nad korzyści własne, godzenie interesów różnych grup społecznych itd. Tak czy inaczej jednak na gruncie gospodarczym ordoliberałowie popierali decentralizację władzy i federalizm państwa, głosili program sprywatyzowania szkół, szpitali, autostrad, energetyki i transportu, w przekonaniu, że prywatna inicjatywa jest bardziej efektywna w działalności gospodarczej i społecznej od państwo- 
wej. Ogólnie wszyscy ordo-neo-liberałowie przyjmują a priori, jako aksjomat, że indywidualne wartości, realizowane przez jednostki w celu zaspokajania swoich prywatnych interesów na wolnym rynku, nieuchronnie muszą prowadzić do powszechnego dobrobytu. Takie są konsekwencje odrzucenia przez nich centralnego planowania, jak przekonywał w latach 70. Friedman (Friedman, 1975, s. 71; zob. też Müller, 2016, s. 295-296; Albert, 1994, s. 135-140).

Przedustawna harmonia przeciwstawieństw lub jedność w różnorodności - to mityczna, fundamentalna przesłanka liberalnego systemu metafizycznego. Nie trzeba wielkiej finezji intelektualnej, żeby ukazać iluzoryczność takiego myślenia, a przy okazji również i jego niszczycielską moc. Za wielką abstrakcją wolnego rynku kryje się bowiem nie tylko niczym nieograniczona radość produkcji i konsumpcji, lecz także „konkretna tresura siły roboczej” (Foucault, 1998a, s. 211). Może wystarczy tylko przypomnieć, że ówczesne „cuda” gospodarcze bywały okupione ogromnymi kosztami społecznymi - takimi chociażby, jakie pociągnęła za sobą wolnorynkowa kuracja górnictwa brytyjskiego. Ale liberalizm w omawianym czasie zasiada także i na ławie oskarżonych o zbrodnie przeciw ludzkości. Junta generała Augusta Pinocheta w Chile (1973-1990) znalazła pomocnika i sojusznika w Stanach Zjednoczonych i ich neoliberalnych ekonomistach, między innymi takich jak przywoływany tu Friedman. Od masowego stosowania tortur, obozów koncentracyjnych - taką funkcję spełniały między innymi dwa największe stadiony sportowe Chile: Estadio Nacional de Chile w Santiago i Estadio Chile (obecnie znany jako Estadio Víctor Jara), w których przetrzymywano około 130 tysięcy ludzi, poddawano ich torturom, rażono prądem; wielu z nich zaginęło bez wieści (zob. np. Larrondo, 2016) - oraz zbiorowych mordów, dokonywanych przez juntę wojskową na własnych obywatelach, dla przedstawiciela chicagowskiej szkoły ekonomii ważniejsze były jej osiągnięcia gospodarcze. Tak pisał on na łamach tygodnika „Newsweek” w 1982 roku: „Chile jest cudem gospodarczym. Inflacja została zmniejszona z 700\% rocznie w połowie 1974 roku do mniej niż 10\% rocznie. (...) Chile jest jeszcze bardziej niezwykłym cudem politycznym. Reżym wojskowy poparł reformy, które gwałtownie obniżają rolę państwa i zastępują kontrolowanie odgórne kontrolowaniem oddolnym" (Friedman, 1982, s. 59). Wniosek: absolutny cel, jakim jest sukces gospodarczy, może być okupiony tyrańską wolą władcy - spontanicznie zgodną (pamiętajmy o przedustawnej harmonii przeciwstawieństw) z dobrem ogólnym, z rozumną wolą powszechną. Taka jest obiektywna norma liberalna. Sprzeciw wobec niej jest wyrazem perfidii, egoizmu i tchórzostwa - niezdolności poświęcenia dobra osobistego na rzecz ogólnych zasad rządzących gospodarką i polityką. Na nowo ożywa nowoczesna mistyczna idea: oświecony władca, dyktator, tyran otwiera drogę do naturalnego, racjonalnego i ostatecznego porządku. Francuscy jakobini robili to samo - i też w imię rozumu. Za tym samym - naturalnym - rozumem opowiadają się chicagowscy ekonomiści w XX wieku. Dlaczegóż mieliby myśleć inaczej? 


\section{Teoria francuska - kontekst powstania}

Wspomniany na początku przełom w teorii politycznej dokonuje się przede wszystkim we Francji - na lewicy zaczyna tam dominować anarchistyczne i antyinstytucjonalne podejście do władzy i państwa. Złożyło się na to wiele różnych powodów. Pisałem już o rewolucji majowej, która była dowodem na to, że dla demokracji, sprawiedliwości i wolności nie ma instytucjonalnych form, które mogłyby zapewnić trwałe urzeczywistnienie się tych wartości i aspiracji (Castoriadis, 2018, s. 110; Dubuy, 2018). Ale to nie wszystko. Do tego dochodzą rozczarowania dekolonizacją Afryki. Przypomnę, że w 1960 roku deklarują niepodległość od Francji między innymi Senegal, Togo, Madagaskar, Niger, Górna Wolta, Wybrzeże Kości Słoniowej - wszystkie te kraje należą do tego, co w owym czasie nazwano Trzecim Światem, który trapiony jest biedą, konfliktami społecznymi i problemami z demokracją. Poza tym na nastroje społeczne i polityczne zapatrywania we Francji mają wtedy także wpływ zwycięskie wojny narodowowyzwoleńcze w Algierii i Wietnamie, jak również rozczarowanie partiami komunistycznymi, wzmocnione najnowszymi „rewelacjami” na temat gułagu (Jameson, 2016, s. 2). Wielkie trzytomowe dzieło Aleksandra Sołżenicyna, Archipelag Gułag. 1918-1956, po raz pierwszy ukazuje się na Zachodzie we Francji w latach 1973-1975. Uważa się, że jego publikacja nigdzie nie miała tak poważnych skutków, jak właśnie tam: intelektualny antykomunizm, jako antytotalitaryzm, i narastające przekonanie, że wszelka myśl polityczna związana z socjalizmem i marksizmem, i w ogóle wywodząca się od Hegla, jest „naznaczon[a] autorytaryzmem" (Müller, 2016, s. 284). W wyniku załamania się przez to całego projektu europejskiej lewicy powstaje wielka ideologiczna pustka, którą niemiecki politolog Jan-Werner Müller tłumaczy tak:

Po Sołżenicynie to prawa człowieka stały się obszarem, na którym zjednoczyć mogli się (zostawiając za sobą dawne zrytualizowane dysputy) długoletni liberałowie, zbuntowani lewicowcy, a nawet część starej lewicy. Stanowiły one program minimum, na którym można było się oprzeć po bankructwie tak wielu innych ideologicznych projektów (Müller, 2016, s. 286).

Szybko okazało się jednak, że prawa te dobrze sprawdzają się jako narzędzie do podważania istniejących na świecie reżymów autorytarnych (przykład Pinocheta pokazuje, że w dużym stopniu jedynie rytualnie i propagandowo), ale są dalece niewystarczające do tego, by sformułować - szczególnie na lewicy - jakiś konkretny program polityczny, który nie podkopywałby ideałów państwowości (Müller, 2016, s. 286-287). Socjaldemokracja programowo domaga się bowiem państwa opiekuńczego - ono zaś domaga się granic i integracji, sformułowania wspólnych celów politycznych.

Otóż, jako się rzekło, ideologiczne podstawy refleksji nad władzą w całym tym kontekście historyczno-politycznym dają tzw. poststrukturaliści - Michel 
Foucault, Jacques Derrida i inni. Władzę traktują oni jako integralny składnik wszelkich relacji społecznych - ekonomicznych, religijnych, moralnych, kulturowych, płciowych - opartych na różnego rodzaju asymetriach: panowaniu, posłuszeństwie, dominacji, przemocy, uległości czy uwodzeniu. Nie sposób więc zredukować jej do państwa - do jurydyczno-politycznego modelu rządzenia. Nasuwają się w związku z tym dwa pytania. Po pierwsze: jak wobec wszechobecności relacji władzy ujawnić jej mechanizmy? Dostęp do takiej wiedzy wymagałby przyjęcia przez teoretyka - a za nim lub wraz z nim i przez jego publiczność, z którą podziela on te same doświadczenia zależności - jakiegoś zewnętrznego punktu widzenia, wolnego od tych uwarunkowań. Po drugie: czy jednak w ogóle można mówić o takim stanie wolności od wpływu na nasze działania przez innych, mających do tego uprawnienia i odpowiednie środki w wymienionych powyżej sferach? Na to pierwsze pytanie - o teorię polityki i jej funkcje - odpowiedź pojawi się w kolejnej części tych rozważań. Co do pytania drugiego, sprawy mają się następująco.

Z przyjętego przez Francuzów punktu widzenia nie ma społeczeństwa bez relacji władzy, bez złożonych oddziaływań na działania wolnych podmiotów $\mathrm{z}$ intencją kierowania nimi. Nie idzie więc o dychotomiczne myślenie przeciwstawiające władzę wolności. Na tym podziale zbudowane są wszelkie utopie społeczne. Ale one zbudowane są na myśleniu mitycznym. Okazuje się, że niestety nie ma powrotu do źródeł, sytuacji pierwotnej - do raju. Między wolnością a władzą zachodzą raczej według Foucaulta relacje agonistyczne, czyli związane z walką lub rywalizacją. „Żyć w społeczeństwie znaczy, w każdym wypadku: działać na cudze działania - i w rzeczy samej czynimy to nieustannie. Społeczeństwo bez stosunków władzy jest abstraktem” (Foucault, 1998b, s. 188). Autor tych słów nie chce zatem wiązać władzy z przemocą jako jej zasadą lub istotą, a tylko jako jej narzędziem lub skutkiem - władza w najszerszym tego słowa znaczeniu jest także działaniem zakreślającym innym pole możliwych działań, jest działaniem na inne działania. Takie jej rozumienie implikuje antydualistyczną ontologię społeczną, to znaczy taką, która nie daje się opisać za pomocą dualizmów typu: fikcyjny - rzeczywisty, teoretyczny - praktyczny, językowy - rzeczowy (słowa - rzeczy), ale także mający władzę - zniewolony.

Brzmi to niczym echo poglądów poprzedniego pokolenia myślicieli egzystencjalnych - ekspresja ich maniakalnych lęków przed wszelką władzą, mającą nieść ze sobą jednostce zniewolenie i uprzedmiotowienie. Upraszczając i nie rozwijając tego tematu, można przypomnieć, że według Jeana-Paula Sartre’a wystarczyło spojrzenie drugiego człowieka, żeby zamienić mnie w rzecz i odebrać mi wolność. „Piekło to inni”. Takie stawianie sprawy, oparte na wielu różnych, mniej lub bardziej ujawnionych, założeniach (epistemologicznych i ontologicznych), wywołuje naturalnie krytykę. I tak na przykład koncepcję Foucaulta postrzega się jako wyraz dystopijnej obsesji, quasi-paranoidalnego strachu przed wszelką formą politycznej lub społecznej organizacji - czy to w formie partii 
politycznej, utopii społecznych, czy też lewicowych programów szermujących w warunkach późnego kapitalizmu pojęciami wolności i demokracji (Jameson, 2016, s. 2). Zdarzają się opinie, które w ogóle odżegnują poststrukturalistów od czci i wiary, odmawiają ich koncepcjom jakiejkolwiek wartości naukowej, przy okazji także i jakiegokolwiek znaczenia dla świadomości aktorów wydarzeń Maja '68. Takiego zdania jest między innymi Cornelius Castoriadis, francuski filozof i psychoanalityk pochodzenia greckiego. Dla niego ruchy społeczne lat 60 . skierowane przeciw ekscesom i patologiom władzy - podważające istniejący porządek: autorytarne rządy gaullistowskie, kapitalizm z jego konsumpcyjnym stylem życia i kolonializmem - były wyrazem pewnej szerszej prawidłowości. Wyjaśnia to następująco:

Wszystko to w oczywisty sposób wiąże się z antynomicznym charakterem nowoczesnej wyobraźni politycznej. Tkwi w niej - z jednej strony - dążenie do autonomii i rozszerzenia jej na kolejne pola życia społecznego; z drugiej strony - zdarza jej się tylko rzadko (i na krótko) uwolnić się od wyobrażenia polityki i instytucji jako wyłącznej twierdzy państwa, a tego państwa (które nadal jest ucieleśnieniem, nawet w najbardziej nowoczesnych społeczeństwach, obrazu władzy z boskiego nadania) jako należącego tylko do samego siebie. Przez to właśnie w czasach nowoczesnych polityka jako działalność zbiorowa (a nie wyspecjalizowana profesja) mogła być dotąd obecna tylko jako spazm i paroksyzm, atak gorączki, zapału i wściekłości, reakcja na ekscesy władzy, skądinąd zawsze zarazem wrogiej i nieuchronnej, będącej wrogiem i przeznaczeniem, krótko mówiąc, jako „Rewolucja” (Castoriadis, 2018, s. 113).

To prawda. Nowoczesna wyobraźnia polityczna ukształtowana jest przez napięcia między uniwersalnością a partykularnością, między Kantowską ideą kosmopolitycznego federalizmu a ideą państwa narodowego, między ideą wolnego rynku przynależnego do kapitalistyczno-burżuazyjnego świata a ideami autonomii jednostkowej i zbiorowej, wyrażającej się w odrzuceniu tego świata, tak jak to było w ruchach społecznych lat 60 . Ale tego rodzaju napięcia nie wyczerpują charakterystyk nowoczesnej polityki. Castoriadis zakłada, że władza ma jedynie charakter jurydyczny. Wiąże się z państwem i jego aparatem represyjnym, który w naturalny sposób prowokuje działania wobec niego naprawcze lub wręcz wywrotowe - rewolucyjne. Wyzwala wtedy ludzkie namiętności i pasje, spazmy, ataki gorączki itp. w imię przywrócenia niezbywalnych praw człowieka. Jako jedyny uprawniony motyw rewolucji, skutkuje on w praktyce, jak uczy historia, pozbawieniem tych praw większość społeczeństwa, albo inaczej mówiąc: obroną wolności „ludu” za pomocą przemocy. Całą władzę przejmują wówczas samozwańczy właściciele „woli ludu”. Mechanizm to dobrze znany. Nie tłumaczy on jednak całego fenomenu władzy, który nie ogranicza się tylko do legalnego używania siły. Poza jurydycznym, zbudowanym na zalegalizowanych formach przymusu, władza ma także charakter produktywny, o czym Castoriadis już nie wspomina. „Odkrycie” jej produktywności zawdzięczamy teorii poststruktural- 
nej, zaliczanej przez niego do nurtu strukturalistycznego, co do którego nie żywi on najmniejszej sympatii, nazywając go „pseudonaukową ideologią” i „niedorzecznościami” (Castoriadis, 2018, s. 111). Na czym dokładnie ta produktywność polega - o tym w następnej części.

\section{Zdekonstruować władzę - nowa teoria}

Co pozostaje wobec tego filozofii - lub szerzej: teorii - polityki, która nie chciałaby albo po prostu nie może zrezygnować $\mathrm{z}$ ambicji emancypacyjnych? Zobaczmy jeszcze raz, co na ten temat ma do powiedzenia teoria, która musiała się pożegnać $\mathrm{z}$ całościowym, systemowym podejściem do państwa i polityki, i z wielkimi opowieściami - -izmami: liberalizmami, funkcjonalizmami - patronującymi tej perspektywie badawczej. Foucault w 1982 roku pisze coś na kształt manifestu metodologicznego, podobnego do tego, który, jak pamiętamy, sformułował trochę wcześniej Touraine. Używając właściwych dla tego typu deklaracji programowych górnolotnych fraz, twierdzi, że "naczelnym zadaniem politycznym, moralnym, społecznym i filozoficznym naszych dni nie jest wyzwolenie jednostki spod władzy państwa. Wyzwalać się musimy zarówno od państwa, jak i od typu indywidualizacji, który nas z nim wiąże. Trzeba promować nowe odmiany podmiotowości, odrzucając tę formę bycia jednostką, którą narzucano nam od kilku stuleci" (Foucault, 2018b, s. 181).

Zapytajmy najpierw: czym są lub być mogą owe „nowe odmiany podmiotowości”, które mają zastąpić nam liberalne, autonomiczne indywiduum? Jak można domniemywać, zarówno w odniesieniu do jednostek, jak i grup - ruchów społecznych (np. tych z lat 60.) podważających zastane instytucje i struktury społeczne - byłyby to podmioty pozbawione centrum, nieskoordynowane i hybrydowe. Nie tyle grupy społeczne w socjologicznym tego słowa znaczeniu (zorganizowane według określonego zbioru wartości, mające zdolność reprodukowania się), ile zbiorowości, amorficzne, spontanicznie zmobilizowane, subwersywne, stawiające opór technokratycznym projektom „postępu”. Dzisiaj zwykle są one zdeterytorializowane - jednocześnie lokalne i globalne, łączące cyberprzestrzeń z przestrzenią miejską (przykład ruchu „Okupuj Wall Street”), rozproszone w swych formach działania i osiąganych efektach. Tak jak to było na przykład z rewolucją oburzonych - hiszpańskich indignados, którą określa się jako „rizomatyczną” (Castells, 2013, s. 144), czyli o strukturze kłącza: to nieprzejrzysty, amorficzny, zagmatwany kłąb wydarzeń, działań, powiązań i zależności. Ich splot nie tworzy żadnego wspólnego efektu, sumującego się na zasadzie synergii, nie przekształca ich w żadną trwałą wspólnotę, grupową podmiotowość. Nie idzie tu już więc o rewolucję, którą miał jeszcze na myśli Castoriadis - wyraz autoekspresji „ludu”, pojętego jako mityczna idea wszystkich jednostek równych 
sobie na podstawie naturalnych praw, działających z siłą niczym jedna pięść jedna wola i jedna całość, realizująca własne wyznaczone sobie cele, skierowane przeciwko państwu, jej wrogowi i przeznaczeniu zarazem.

Teoria zrywająca $z$ tą wielką fantastyczną opowieścią ma promować podmioty znacznie bardziej słabe i nieokreślone niż ów „lud” lub „masy”, w które zdążył on się przeobrazić z biegiem czasu. Nadal nie wyzbyła się ona jednak strachu i podejrzliwości wobec państwa - dlatego stawia sobie za zadanie "promować" słabszych, uodpornić lub uwrażliwić ich na zmasowane oddziaływanie mechanizmów, za pomocą których państwo czyni z nich autonomiczne jednostki. Oto ów paradoksalny, nietzscheański stan ujarzmionej wolności, który otwiera pole działania dla filozofii i pozwala jej spełnić się zarówno w swej funkcji źródłowej - terapeutycznej, związanej z platońską psychagogią, czyli troską o duszę - jak i krytycznej. Tak jak filozofia od czasów Kanta miała "przeciwdziałać wykraczaniu rozumu poza granice dostępnego mu doświadczenia”, tak „począwszy od tej samej cezury, którą wyznacza początek nowoczesnego państwa oraz planowego zarządzania życiem społecznym, misja filozofii polega również na czuwaniu nad wymykającymi się spod kontroli mocami racjonalności politycznej - z pewnością nie jest to mało" (Foucault, 1998b, s. 176) - dodaje na pocieszenie Foucault. „Czuwanie” lub „promowanie" w jednym i drugim przypadku to tyle, co pielęgnowanie, troszczenie się o coś, sprawowanie pieczy nad czymś. Nad czym? Nad ekscesami racjonalności politycznej. W jaki sposób? Metoda ma polegać na połączeniu podejścia terapeutycznego - odwołującego się do kulturowo umocowanych technik dbania, troszczenia się o siebie, czuwania nad sobą (np. techniki ascezy, medytacji, badania siebie pod względem ujawniania wewnętrznych myśli, ich stosunku do norm społecznych itd.) (Foucault, 2000, s. 247-275) - z podejściem krytycznym, nastawionym na ujawnianie sztuczności ładu społecznego, który pretenduje do bycia naturalnym. Podmiotowość widziana w ten sposób, od wewnątrz i z zewnątrz zarazem, pozwala uchwycić wszelkie mechanizmy władzy, jakim ona podlega. Ujawnić, że wrogami podmiotu - w znaczeniu, o którym tu mowa - na równi są systemy autorytarne, jak i demokratyczne, że nawet takie patologie władzy, jak faszyzm czy stalinizm, nie wniosły nic nowego do logiki lub racjonalności jej funkcjonowania, a jedynie wykorzystały i rozbudowały mechanizmy i narzędzia obecne już w innych społeczeństwach. Bynajmniej nie oznacza to jednak, że przyjęta metoda analizy polityki i władzy pozwoli stworzyć jej teorię, taką, dodajmy, która byłaby oparta na Arystotelesowskim w swej genezie modelu rozumu teoretycznego. Przeciwnie, ponieważ to właśnie dekonstrukcja jest jej narzędziem i zarazem efektem poznawczym. Na poziomie świadomości badacza podejście to wiąże się z przekonaniem, że nigdy nie stanie on twarzą w twarz wobec badanego zjawiska, nie dotrze do jego podstaw, istotnych własności. Prawdę mówiąc, nie tyle go on wyjaśnia, ile zaciemnia, czyni tajemniczym i nieokreślonym. 
Nie wszyscy skłonni są zgodzić się na to, że teoria, która „zaciemnia i czyni tajemniczym i nieokreślonym”, nadal zasługuje na miano „teorii”. Krytycy twierdzą wręcz, że "teoria dekonstrukcyjna” to wyrażenie absurdalne, w związku z czym po dekonstrukcji automatycznie nie ma już żadnej teorii - nie tylko politycznej. Obawiam się, że u podłoża tego rodzaju zarzutów ostatecznie kryje się spór natury ideologicznej, a więc zasadniczo nierozstrzygalny. Spróbuję jednak mimo wszystko, nie wchodząc w szczegóły, przypomnieć kilka argumentów na rzecz zasadności dekonstrukcjonistycznych/poststrukturalistycznych roszczeń do teorii.

Po pierwsze, utrzymywanie, że istotą dekonstrukcji ma być niemożność jakichkolwiek konstatacji - w interesującym nas przypadku wypowiedzi o rzeczywistości politycznej - jest nieporozumieniem. Takie stanowisko oznaczałoby ni mniej, ni więcej tylko podważenie sensowności - posądzenie o absurdalność wszystkiego, co osiągnęła humanistyka i nauki społeczne powiązane z tzw. zwrotem lingwistycznym (zob. np. Rasiński, 2009; Markowski, 2010). Zwrot ten nie „znosi” „logiczności” ani języka naukowego, ani języka naturalnego, ani jakiegokolwiek innego - mówi co najwyżej o tym, że sam podział na "naukowość” i „naturalność” nie polega na wypowiedziach, które bezpośrednio odnoszą się do swych korelatów - do samych rzeczy „naukowych” lub „naturalnych”. Że nie ma czegoś takiego, co byłoby samo w sobie - ze swej istoty - „naukowe” lub „naturalne”. Wypowiedzi o „realności”, o „rzeczach”, „faktach” i „istotach” stają się logiczne, otrzymują wartość prawdy lub fałszu na podstawie reguł istnienia obowiązujących przedmioty, które są tak nazwane. To zatem zbiory takich reguł, czyli - innymi słowy - dyskursy, umożliwiają formowanie się przedmiotów - „naukowych”, „politycznych”, „naturalnych”, „religijnych”, „artystycznych” itd. - tworzą "warunki ich historycznego zjawiania się" (Foucault, 2002, s. 55). Dekonstrukcyjna teoria polityki ukazuje i wyjaśnia dyskursywne mechanizmy konstruowania się takich dziedzin przedmiotowych. Nie ma ona ambicji legitymizacyjnych - i tym zasadniczo różni się od klasycznego modelu teorii, do omówienia której niniejszym przechodzę.

Po drugie, zarówno pojęcie „dekonstrukcji” - u jego twórcy, Jacques’a Derridy - jak i „teorii” - w historycznych użyciach tego terminu - nie jest ani jednoznaczne, ani łatwe do zdefiniowania (Banasiak, 1993; Hudzik, 2011; Hudzik, 2017). Wiadomo, że analiza dekonstrukcyjna rozprawia się z teorią w ujęciu klasycznym, Arystotelesowskim - pozbawia jej twierdzenia o statusie bytowym danych rzeczy (np. politycznych) zdolności do ich (tych rzeczy) wyjaśniania i legitymizowania. Analiza dekonstrukcyjna polega na ukazaniu, że twierdzenia tej teorii nie stykają się bezpośrednio, twarzą $\mathrm{w}$ twarz, $\mathrm{z}$ „istotami” rzeczy. Zawarta $w$ tej teorii koncepcja kontemplacji, jako intuicyjnego, samocelowego oglądu tego, co w rzeczach jest podstawowe, istotne, czyli tzw. pierwszych zasad (Arystoteles, 1983, s. 7), w wyniku dekonstrukcji jawi się jedynie jako dyskurs, reguły istnienia obowiązujące przedmioty, które są w niej nazwane i opisane, oraz 
praktyki społeczne - relacje władzy w starożytnych Atenach - które one afirmują i legitymizują.

Derrida łączy klasyczny model teorii w ogóle z zachodnim „logocentryzmem" - wizją świata opartą na rozumności, uniwersalności i hierarchiczności, wynikającej z prymatu teorii nad praktyką. Należy przy tym pamiętać, że dla niego, podobnie jak i dla pozostałych tzw. poststrukturalistów, synonimem takiej teorii był jednak przede wszystkim strukturalizm - ucieleśnienie scjentystycznego mitu, wedle którego celem nauki jest badanie obiektywnych faktów i odkrywanie uniwersalnych praw nimi rządzących. Przypomnijmy, że Claude Lévi-Strauss karmił się tym samym co Arystoteles mitem - teraz konsekwentnie trzeba by powiedzieć: dyskursem - o bezpośredniości bytu, choć oczywiście w innym już kontekście kulturowym, który naukę umieścił w perspektywie epistemologicznej (po tzw. przełomie nominalistycznym). Mówił on o badaniu faktów „ze względu na nie same” (Lévi-Strauss, 1970, s 368) - o czystej obserwacji, nieskażonej żadnymi wstępnymi, teoretycznymi założeniami. Podobne marzenia o bezpośredniości oglądania przedmiotów we „własnej osobie” dzięki tzw. redukcji fenomenologicznej znamy z opowieści Edmunda Husserla. Zostawmy jednak te skojarzenia. „Właściwym przedmiotem” analizy strukturalnej - według francuskiego antropologa - miały być już jednak tylko modele (Lévi-Strauss, 1970, s 367-369) - uniwersalne struktury, nieświadome, głęboko ukryte w naszych umysłach mają tłumaczyć i uprawomocniać funkcjonowanie wszystkich dostrzeżonych faktów. Analiza dekonstrukcyjna potrafi wykazać, że struktury te spełniają dokładnie tę samą funkcję co Arystotelesowskie „pierwsze zasady”.

Po trzecie, z punktu widzenia Derridy obydwie te wersje klasycznego modelu teorii odnoszą się tylko do - mówiąc po Heideggerowsku - Vorhandenes, czyli bytu jako czegoś odkrytego, obecnego, określonego. Dekonstrukcja jest teorią niemożliwości takiej właśnie teorii. Nadal jest jednak teorią, choć już inaczej pojmowaną. Teoria po dekonstrukcji - jak wyjaśnia Anna Burzyńska, autorka książki pod znamiennym tytułem Anty-teoria literatury, szczegółowo omawiającej to zagadnienie - „oznacza ponowne przemyślenie statusu teorii jako dyscypliny, jej powinności i możliwości jej uprawiania” (Burzyńska, 2006, s. 29). Teoria na nowo zdefiniowana przestaje być dyskursem wyjaśniającym i uprawomocniającym wszelkie formy odkrywczego obchodzenia się z rzeczywistością. Zamiast nastawienia na dystans i chęć obiektywizowania świata, sama staje się jego częścią, rodzajem praktyki, dla której źródłem sensu nie jest już byt - logos - lecz ślad - coś, co jest niejednoznaczne, co jest poza metafizyką, opiera się logosowi i co dlatego też „nie może być uznane za przedmiot jakiejś nauki (...) [i] nie daje się zredukować do postaci obecności" (Derrida, 1999, s. 88). Skoro nie ma esencji, to nie ma też i czystych realizacji ani teoretyczności, ani antyteoretyczności - koniec teorii i antyteorii to początek teorii jako praktyki dyskursywnej, „praktyki pisania” (Burzyńska, 2006, s. 29). 
I tak też należałoby traktować dekonstrukcyjną teorię polityki - po rzeczonym zwrocie lingwistycznym jej zadanie polega na ujawnianiu, że słowa i pojęcia nabierają $\mathrm{w}$ teorii sensu nie $\mathrm{z}$ rzeczy samych $-\mathrm{z}$ bytu i rządzącego nim logosu - lecz ze śladu, czyli z różnicości (différance) (Derrida, 1999, s. 98). Ślad natomiast, jak tłumaczy francuski filozof, polega na "nie-obecności innego wpisanej w sens tego, co obecne" (Derrida, 1999, s. 106). O co chodzi? Otóż jeśli różnicę nie uznamy za przeciwieństwo tożsamości, lecz za jej integralny składnik, to musimy też zgodzić się z tym, że nie uda nam się tak łatwo do niej zbliżyć, że kontakt $\mathrm{z}$ nią $\mathrm{w}$ praktyce zamieni się w nieskończone odwlekanie jej ujęcia. Można by dalej pytać: a kiedy my czegoś takiego doświadczamy? Wtedy chociażby, gdy podejmujemy grę z powierzchniami rzeczy, pod którymi nic się nie kryje, z fragmentami, które nie mają odniesienia do żadnej całości, z peryferiami, które nie mają centrów, ze znaczącymi, które nie mają swojego znaczonego, z tekstami, które nie mają innych przedmiotów odniesienia poza kolejnymi tekstami... Analiza dekonstrukcyjna ujawnia, że tak właśnie jest z tym wszystkim, co pojawia się nam jako zrozumiałe, bliskie i obecne - i czyni to na powrót nieokreślonym i „tajemniczym” (Derrida, 1999, s. 105). Zadanie teoretyka polega wobec tego na tym, by nagłośnić różnicę nawet za cenę porzucenia powagi ascetycznego kapłana i przyjęcia postawy gracza, ironisty, uwodziciela lub prowokatora, pogodzonego ze świadomością, że język, którym się posługuje, nigdy nie może uzasadniać w sposób całkowity i ostateczny (Derrida, 1999, s. 104-106; Hudzik, 2016, s. 16-17). I że właśnie dlatego on, na tych samych warunkach co każdy z nas, nigdy nie jest w stanie całkowicie nad polityką zapanować, zbliżyć się do niej, zobiektywizować ją, ogarnąć w całości jej znaczeń, funkcji i oddziaływań. Teoria dekonstrukcyjna, mówiąc po derridowsku, jest farmakonem - trucizną i lekarstwem zarazem - „niebezpiecznym uzupełnieniem”, w którym coś, co się uobecnia, znika zarazem (Derrida, 1993, s. 60-61).

Wiedza, którą w ten sposób teoretyk produkuje, nie spełnia więc ani kryteriów adekwatności, ani kanonów naukowości obowiązujących w znanych dotychczas teoriach polityki - empirycystycznych i funkcjonalistycznych. Nie stworzy on dlatego teorii, która byłaby prosta (w sensie: wprowadzająca porządek do zjawisk, bez którego nie pozostawałyby one ze sobą powiązane), dokładna (której konsekwencje pokrywałyby się z wynikami badań empirycznych) czy wreszcie spójna (wewnętrznie, wedle kryterium niesprzeczności twierdzeń, i zewnętrznie $-\mathrm{z}$ innymi teoriami stosowanymi do pokrewnych zjawisk). $Z$ całego, pięcioczłonowego zestawu kryteriów teorii naukowej wyróżnionych swego czasu przez Thomasa S. Kuhna dekonstrukcyjna teoria mogłaby co najwyżej być ogólna (jej zakres wychodzi poza indywidualne przypadki) i owocna, czyli zdolna dokonywać za ich pomocą nowych odkryć (Kuhn, 1985, s. 442). Przykłady za chwilę.

Analiza dekonstrukcyjna władzy w rezultacie ujawnia, że nigdy nie jesteśmy w stanie całkowicie nad nią zapanować ani uwolnić się od niej, że u podstaw 
tego, co polityczne - prawa, instytucji państwa - tkwi zawsze coś nieokreślonego. Musimy zatem odrzucić myślenie o niej oparte na przeciwstawianiu władzy wolności i pogodzić się z jej nieprzejrzystością - postrzegać ją jako zbiór rozmaitych, złożonych oddziaływań na działania innych podmiotów: prowokowania, zachęcania, uwodzenia, ułatwiania lub utrudniania, czasem wymuszania lub zakazywania (Foucault, 1998b, s. 187). Ani nie wychodzi się więc tu od analizy porządku prawnego, ani do niego nie ogranicza - przedmiotem badania jest to „jak" władzy: jak ona działa, jakimi środkami się ją sprawuje, jakich technik używa. Tymi wszystkimi aspektami interesują się także współczesne nauki o polityce. One również chcą badać władzę szeroko, jako szczególny rodzaj relacji, wartości i funkcji (Karwat, 2018, s. 89) - i bynajmniej nie zamierzają rezygnować, w imię scjentystycznych ideałów naukowości, z ambicji emancypacyjnych, opartych na postawie nazwanej tu metaforycznie „czuwaniem”. Zakłada się, że dopiero takie podejście umożliwi bowiem wyczerpujące analizy oddziaływania polityki we wszystkich trzech - wyróżnionych przez Mirosława Karwata - płaszczyznach: gry politycznej (między aktualnymi i potencjalnymi podmiotami władzy, której rezultat zależy od szeregu okoliczności, wśród nich wielu niedających się z góry ani przewidzieć, ani zbadać), rządzenia (relacji między podmiotem posiadającym uprawnienia i środki do egzekucji swej woli a tymi, których działaniami on kieruje), wreszcie nacisku społecznego (dynamicznego sprzężenia zwrotnego między rządzącymi i rządzonymi, ich wzajemnego oddziaływania, presji otoczenia lub opinii publicznej na instytucje państwa) (Karwat, 2018, s. 79-81).

Mowa tu o teorii społecznej nawiązującej do udziału języka w stanowieniu rzeczywistości. Według niej polityka, jako praktyki dyskursywne - używane w danym miejscu i czasie, historycznie zmienne i dezaktualizujące się sposoby nazywania, określania, dyskutowania i działania - uzyskuje znaczenie tylko wtedy, kiedy jest interpretowana w kategoriach społecznych, stanowi integralną część naszej rzeczywistości społecznej - i w tym sensie jest przez nie (przez owe praktyki) konstruowana. Ujawnić ten stan rzeczy to tyle, co go zdekonstruować - ukazać jego sztuczność, umowność, podatność na modelowanie i przeobrażanie. Czuwanie nad możliwymi ekscesami i patologiami władzy, na poziomie gry, rządzenia czy nacisków, powściąganie produktywnych mocy jej racjonalności, to $\mathrm{z}$ omawianego punktu widzenia nie tyle arbitralny wybór, ile raczej integralny element tożsamości - samoświadomości - nowoczesnej teorii polityki.

Opisywana teoria, jak powiedziałem, potrafi uogólniać. Wykazuje na przykład, że również i liberalne podmioty produkowane są przez państwo w kapitalistyczno-burżuazyjnym świecie, choć państwo to nie musi już ich represjonować przez autorytarne, przednowoczesne formy władzy. Także i one nie są więc żadnymi naturalnymi, wolnymi jednostkami. Przywołam jeden ze znanych opisów, które Foucault zamieszcza w swej głośnej książce z 1975 roku - Nadzorować i karać - wyjaśniając fenomen dyscypliny - kluczowego dla nowoczesności me- 
chanizmu kontroli społecznej. Współczesne mu społeczeństwo uwięzione - jak powiada - w "machinie panoptycznej” przeciwstawia on starożytnej cywilizacji spektaklu, w których świątyniach, teatrach i innych rozwiązaniach architektonicznych wielkiej masie udostępniane było oglądanie niewielkiej liczby przedmiotów. Panoptyzm ma być odwrotnością tej sytuacji: niewielkiej grupie ludzi dany ma być nadzór nad masami - ludzi, zjawisk, przedmiotów.

Społeczeństwo nasze nie jest społeczeństwem spektaklu, ale nadzoru; pod zasłoną obrazów kryje się blokowanie ciał, za wielką abstrakcją wolnego rynku trwa drobiazgowa i konkretne tresura siły roboczej, obieg informacji jest wsparciem kumulowania i centralizacji wiedzy, migotanie znaków sygnalizuje kotwicowisko władzy, spektakularna integralność jednostki ludzkiej nie jest ani amputowana, ani tłumiona, ani zniekształcana przez nasz ustrój - przeciwnie, on ją pieczołowicie fabrykuje zgodnie ze skomplikowaną taktyką sił i ciał (Foucault, 1998a, s. 211).

Podmiot podległy nadzorowi to już nie żadne autonomiczne „Ja", którego wolność miałaby być mierzona siłą oporu, jaki stawia on władzy państwowej, jak uważają w tym samym czasie wywołani powyżej liberałowie. Rzecz ma się dokładnie odwrotnie: jego wolność jest raczej korelatem tej władzy, jej produktem (Müller, 2016, s. 295-296). I tak jest - tu uogólnienie - w przypadku każdego rodzaju władzy: każda ujarzmia, kontroluje, czyni sobie ludzi poddanymi zarówno poprzez zewnętrzną nad nim kontrolę - instytucje społeczne i polityczne - jak i wewnętrzne na nich oddziaływanie, wpływanie za pomocą języka, kulturowych ram percepcyjnych na ich samowiedzę, sumienie czy jakkolwiek inaczej to nazwać.

Na tym właśnie polegają produkcyjne moce władzy, fakt, że nie tylko mówi ona „nie”, nie tylko jest represyjna, lecz także atrakcyjna - tworzy coś nowego, formułuje dyskursy, gromadzi wiedzę na temat tych, którzy jej podlegają, i świata, w którym oni żyją. Może pociągać czarem samej siebie, ale może także zaspokajać inne potrzeby, służyć „kompensacji kompleksów, uzyskaniu komfortu psychicznego i materialnego, nasyceniu żądzy odwetu, zemsty itd." (Karwat, 2018, s. 90). W każdym jednak z tych przypadków swoją partykularność będzie starała się ukryć za zasłoną przypisanych sobie uniwersalności - o charakterze politycznym, moralnym, religijnym lub innym - które nadają wiarygodność binarnej relacji między tym, co „naturalne”, „rzeczywiste” czy „ważne” dla mnie, dla nas, dla państwa, a tym, co „nierzeczywiste”, „nieważne”, „marginalne” itd. Przed możliwymi ekscesami wszystkich tych przedefiniowań ma uchronić nas czujność teoretyka. Dość słaby to bastion bezpieczeństwa w świecie niosącym ze sobą zewsząd zagrożenia, ale innego dekonstrukcja nie przewiduje.

Dzisiaj czas rewolucji zdaje się wygasł, wymagane dla niej wielkie struktury społeczne uległy zniszczeniu. Zagrożenie dla państwa w ponowoczesności ma już inne źródła niż wzniosłe rewolucyjne przedsięwzięcia - powstaje w wyniku cedowania przez niego swojej suwerenności na rzecz prawa międzynarodowe- 
go, światowego kapitału czy organizacji i korporacji transnarodowych. Według niektórych teoretyków procesy te są również destrukcyjne dla samej teorii polityki, której istotnym przedmiotem tradycyjnie było państwo jako takie, znane od czasów greckiego polis (Jameson, 2016, s. 20-22). I może właśnie dlatego nadal owocnie, przekonująco i alarmująco brzmią w tych warunkach obrazoburcze hasła dekonstrukcji: śmierci podmiotu, człowieka, sensu, historii, a za nimi nieuchronnie także i śmierci polityki.

\section{Przemoc i uwodzenie}

Jak jednak owo teoretyczne czuwanie wygląda w rzeczywistości? Pytanie to jest o tyle zasadne, że z omawianego tu punktu widzenia relacje władzy, nierozerwalnie związane z życiem społecznym, rozciągają się też na działania samych tych teoretyków. Jak więc mogą oni ujawnić mechanizmy władzy, skoro sami im podlegają, i co więcej - sami także nieuchronnie je stosują? Następny po Foucaulcie na liście najgłośniejszych poststrukturalistów Jacques Derrida tak pisze o przemocy, do której posuwają się teoretycy:

Trzeba przyznać, że w dyskusjach akademickich czy intelektualnych w ogóle dochodzi do głosu polityczna lub jeszcze inna przemoc. Mówiąc to, nie zachwalam pogodzenia się z tą przemocą, ale przede wszystkim domagam się próby rozpoznania jej i przeanalizowania, jak to tylko możliwe, we wszystkich formach, maskach i przebraniach instytucjonalnych czy indywidualnych, dosłownych czy metaforycznych, szczerych czy towarzyszących hipokryzji, z czystym lub nieczystym sumieniem. A ponieważ, jak sądzę, przemoc jest w rzeczywistości (prawie) nieredukowalna, analiza przemocy i wyrafinowane liczenie się z jej warunkami to gesty najmniej obciążone przemocą, być może gesty bez przemocy, a w każdym razie gesty, które najlepiej przyczynią się do przekształcenia prawno-etyczno-politycznych reguł: $w$ uniwersytecie i poza uniwersytetem (cyt. za: Hmissi, 2005, s. 92-93).

Każda wypowiedź jest propozycją jakiegoś nowego bądź akceptacją zastanego porządku społecznego - prawno-etyczno-politycznego - i wyklucza tym samym inne możliwości, $w$ tym sensie jest pewnym działaniem, ingerowaniem w rzeczywistość. Przemoc językowa to społeczna praktyka - „jest w rzeczywistości (prawie) nieredukowalna" - dlatego dla świadomych tego faktu intelektualistów jest pewnym wyzwaniem, domaga się drobiazgowych analiz językoznawczych, wykorzystujących takie metody badawcze, jak analiza semantyczna, krytyczna analiza dyskursu czy analiza dekonstrukcyjna. A wszystko to po to, żeby zdetonować przemoc, rozłożyć ją na części składowe - „wyrafinowane liczenie się z jej warunkami” - obnażyć jej mechanizmy z natury chytre, nieczytelne dla zdrowego rozsądku - synonim ufności i otwartości na świat - ukryte pod maskami i przebraniami konwencjonalnych dobrych i przyzwoitych za- 
chowań. Taka demaskacja sama w sobie to nie tyle - autor cytowanego tekstu jest tutaj powściągliwy - dobra robota kogoś zdystansowanego wobec tego rodzaju praktyk, ile jednego z ich uczestników, aktorów na scenie publicznej, wykorzystujących jednak w swej grze trochę inne niż reszta obsady "gesty”, zdolne zmienić dramaturgię przedstawienia, ale nie samo przedstawienie. "Gesty” mogą zmienić jedynie reguły - prawno-etyczno-polityczne - gry aktorskiej. A to by znaczyło, że dyskurs akademicki/naukowy/intelektualny nie różni się istotnie od dyskursu politycznego czy publicznego w ogóle, że między uniwersytetem a światem zewnętrznym nie ma wyraźnej linii demarkacyjnej - jeśli już takowa istnieje, to zgodnie z poetyką reguł przygodnych tylko doraźnie, jako rezultat porozumienia, i na czas jego obowiązywania, obydwu stron co do swoich zakresów autonomii.

Poststrukturaliści stoją zatem na stanowisku, że każdy język, którym się posługujemy, wszelkie nasze wypowiedzi potencjalnie wpisują się w dyskurs polityczności - „nie wychodzi się z niego nigdy” (cyt. za: Baudrillard, 2014, s. 53), jak powie Foucault, a Chantal Mouffe doda: „polityczność należy do naszej ontologicznej kondycji” (Mouffe, 2008, s. 32). Zadanie teoretyków polegałoby w takim razie jedynie na tym, jak ujmie to tym razem Jean Baudrillard, „aby uchwycić radykalną nieokreśloność polityczności, jej nieistnienie i symulację oraz to, co od tego momentu podsuwa władzy lustro pustki” (Baudrillard, 2014, s. 53), i pokazać przez to władzy politycznej, że jest iluzoryczna („lustro pustki”), że „przemoc symboliczna [jest] porywająca bardziej niż jakakolwiek przemoc polityczna" (Baudrillard, 2014, s. 53). Nikt nie konstruuje tu więc - tak jak powiedzmy Jürgen Habermas - modelowych sytuacji komunikacyjnych, w których rozmowa, wolna od panowania i przemocy, miałaby prowadzić do porozumienia. Przeciwnie, wszyscy przywołani tu autorzy są otwarci na przygodność samych siebie, na myślenie i komunikowanie nieliniowe, odwracalne, na nieprzejrzystość własnych intencji i własne uwikłanie w język oraz kulturowe ramy postrzegania świata. Podważają oni tym samym także (scjentystyczne) charakterystyki własnego dyskursu tożsamościowego - obiektywizm, bezstronność i neutralność. Obnażają ich iluzoryczność, umowność, abstrakcyjność.

Przedstawiam tu sposób myślenia, którego inicjatorką jest Hannah Arendt. Jak wiadomo, wskazywała ona na "potencjalny" charakter władzy - wywodząc go etymologicznie od greckiej dynamis, łacińskiej potentia, i ich nowożytnych pochodnych, na przykład niemieckiego Macht, wywodzącego się od mögen, möglich, czyli od tego, co możliwe - i przeciwstawiała go „aktualnemu”, który polega na stosowaniu przymusu i gromadzeniu w tym celu środków siłowych. Arendt pisze: „Władza urzeczywistnia się tylko tam, gdzie (...) słowa nie są puste a czyny brutalne, gdzie słów nie używa się do ukrycia zamiarów, lecz do odsłonięcia tego, co rzeczywiste, a czyny nie służą do zadania gwałtu i zniszczenia, lecz do ustanowienia powiązań i tworzenia nowych rzeczywistości” (Arendt, 2000, s. 219). Za tą intuicją, odrywającą władzę od stosowania siły, podążają przywo- 
ływani tu poststrukturaliści - dla nich również władza nie jest już niczym substancjalnym, jak utrzymywały nauki społeczne od czasów Maxa Webera. Łączą oni władzę z wszelkimi relacjami społecznymi, z samoczynnym ustanawianiem przez społeczeństwo porządku w przygodnym świecie. Nie rządzi tym procesem żadna aprioryczna racjonalność, uprzednia wobec praktyki. Uświadomienie sobie tego stanu rzeczy wymaga wyjścia poza znane dotąd ramy dyskursu naukowego, który zakłada istnienie apriorycznych racjonalności w postaci modeli wyjaśniających i idealizacji. Wyjście poza tego rodzaju wielkie „budowle pojęciowe” - i tu śmiało posłużę się słowami weimarskiego klasyka - które „promieniują w logice rygorem i chłodem właściwym matematyce” (Nietzsche, 1993, s. 190) to tyle co uzgodnienie się z przygodnością i nieokreślonością relacji władzy, by nie rzec: umiłowanie tego stanu rzeczy - choć to właśnie nietzscheańskie amor fati niewątpliwie było pierwotną inspiracją dekonstrukcji. Stąd też i odziedziczona przez jej teoretyków po Nietzschem tendencja do przesady, prowokacyjny język, radykalne formuły typu „nieistnienie” i „symulacja” w odniesieniu do polityczności (jak wyżej, Baudrillard), twierdzenia o „hegemonicznej naturze każdego typu ładu społecznego” i jego przygodności, jako „braku ostatecznej podstawy” i „nierozstrzygalności przenikającej wszelki porządek” (Mouffe, 2008, s. 32; Hudzik, 2016).

Zobaczmy w takim razie, cóż owocnego powie nam opisywane tu podejście do relacji władzy, w których jesteśmy uwikłani na co dzień, my - publiczność ponowoczesnych konsumentów. Nowoczesność dawno temu przestaliśmy już kojarzyć z procesami racjonalizacyjnymi lub dyscyplinarnymi, o których tak wymownie pisał jeszcze w latach 70. Foucault. Wiążemy ją już raczej z rzeczywistością charakteryzującą się symboliczną i estetyczną lekkością bytu. Co kryje się za tą zgrabną literacką frazą? To mianowicie, że na co dzień za model lub ramy percepcji rzeczywistości służy nam obraz telewizyjny i komputerowy. Że czerpiemy radość - i zyski - nie tyle z produkcji węgla i stali, ile $\mathrm{z}$ wiedzy $\mathrm{i}$ informacji, nowych technologii i materiałów, sprawiających nam same przez się przyjemność, na ogół bez względu na ich walory ekonomiczne czy funkcjonalne. Nic dziwnego zatem, że wobec takiej zbiorowości - już nie ludu, nie masy ani grupy społecznej czy wspólnoty - także i władza polityczna jest najbardziej skuteczna - czyli potrafi na przykład rozwiązywać jej problemy czy też zapewnić jej konsolidację - wtedy, gdy narzuca jej swoje wizje za pomocą środków symbolicznych i estetycznych, oczywiście nie rezygnując przy tym z siłowych resortów i form oddziaływań. Podmioty polityczne, osoby lub instytucje, mają być telegeniczne, w komunikacji używać języka nowych mediów, wchodzić w interakcję z różnymi grupami internautów - tweetować i blogować - korzystać z całego zasobu narzędzi, metod i technik public relations. Przejmują wówczas kontrolę społeczną poprzez uwodzenie. Mechanizm ten Baudrillard wyjaśnia następująco: 
Uwodzenie jest silniejsze od władzy, ponieważ jest procesem odwracalnym i śmiertelnym, podczas gdy władza uznaje się za niewymienną jako wartość, kumulatywną i nieśmiertelną z istoty - przejmuje wszelkie złudzenia realności i produkcji, uznaje się za porządek realności i buja w ten sposób w wyobrażeniu oraz dotyczącym siebie przesądzie (za pomocą teorii, które ją analizują, choćby po to, aby jej zaprzeczyć). Nie jest nigdy z porządku siły ani ze stosunku siły. Precyzyjnie rzecz ujmując, to ono otacza cały realny proces władzy, podobnie jak cały realny porządek produkcji, tą nieustanną odwracalnością i dezakumulacją, bez których nie byłoby ani wła$d z y$, ani produkcji (Baudrillard, 2014, s. 40-41).

Uwodzenie nie polega na oddziaływaniu siłowym i nie podlega kumulacji zdaje się więc władzą par excellence w arendtowskim tego słowa znaczeniu. Ma być „procesem odwracalnym i śmiertelnym”, czyli takim w sam raz na ludzką miarę. Zdemaskowane - przestaje działać. Natychmiast tracą na atrakcyjności wszelkie środki i techniki stosowane przez władzę (tu synonim relacji siłowej), bo ono samo nią nie jest, lecz jedynie „otacza” cały „realny proces władzy” i „realny porządek produkcji”. Podkreślenie realności władzy i produkcji ma pokazać, że uwodzeniu przysługuje inny sposób istnienia i stosuje się do niego inna ontologia. Jest ono mianowicie czymś nie-realnym w sensie: wirtualnym, otaczającym - uwikłanym w - to, co realne - doraźne, kruche i zmienne w czasie. To, co otacza, oddziałuje na to, co mieści się wewnątrz, wywiera na to wpływ, ale nie jest jego właściwością, i w ogóle nie jest niczym substancjalnym, określonym, finalnym. Ma naturę płynną i niejednoznaczną, dostosowuje się do każdorazowo innych kształtów rzeczy. Zjawiska i relacje społeczne są przecież dynamiczne. Bardziej odpowiada więc uwodzeniu istnienie procesualne - rozgrywa się w czasie, a jego spoiwem jest mechanika gry, która wykorzystuje przypadek, ale oparta jest też i na regułach - środkach i technikach, za pomocą których władza w danym miejscu i czasie „produkuje” rzeczywistość społeczną.

To dobra ilustracja języka i stylu, którym posługują się poststrukturaliści. Rezultat odrzucenia funkcjonalizmu i naukowego języka abstrakcji. Teraz w jego miejsce wchodzą metafory, a zamiast powagi - ironia, prowokacja i intertekstualne gry: parodie, aluzje i cytaty. Tylko takie środki wyrazu mogą oddać bezpodstawność, nierozstrzygalność i nieokreśloność władzy i tego, co polityczne, a właściwie należałoby powiedzieć: mogą zbliżyć się zaledwie do tego, co je otacza. I w ten sposób oczarować i przyciągnąć swoich czytelników, pokierować nimi - zatroszczyć się o nich. O nas cierpiących na przewlekły stres i depresję, choroby cywilizacyjne w świecie miotanym nieustannymi konwulsjami między rygorem i chłodem ekonomicznej dyscypliny - kalkulacją, wydajnością i innowacyjnością - a ciepłym, estetycznym, uwodzicielskim czarem i rozprężeniem konsumenckiej publiczności. 


\section{Polityka i władza, która nie istnieje}

Optymizm autorki Kondycji ludzkiej nie zdołał się przebić do młodszego pokolenia filozofów reprezentowanego przez Derridę, Foucaulta, Baudrillarda i innych (Hudzik, 2016). Utrzymują oni, że nie istnieją enklawy w domenie społecznej neutralne, niepolityczne, wolne od relacji władzy jako panowania, narzucania pewnych porządków racjonalności, symbolicznych zakodowań świata, zawsze jakoś zhierarchizowanych, a więc także przemocogennych - nie da się oddzielić politycznego od naukowego, praktyki od teorii, poiesis od theoria. „Nauczanie jak mówi w swoim wykładzie o uniwersytecie bezwarunkowym Derrida - polega zawsze na akcie słowa performatywnego, nawet jeśli wiedza, przedmiot, treść tego, co ktoś wyznaje, czego naucza lub czym się zajmuje, należy właśnie do porządku teoretycznego lub twierdzącego" (Derrida, 2014, s. 46). Derrida generalizuje pewne ustalenia filozofii analitycznej. Przypomnę: zdania performatywne, typu „nadaję imię" czy „biorę tę kobietę za żonę” - których nazwa pochodzi od angielskiego czasownika „perform”, występującego z rzeczownikiem oznaczającym czynność - wskazują, jak tłumaczy John Langshaw Austin w swoich wykładach pod tytułem Jak działać słowami (1955 r.), że „wygłoszenie jest wykonaniem jakiejś czynności, jest czymś, o czym nie myśli się normalnie jako tylko o powiedzeniu czegoś" (Austin, 1993, s. 555).

Francuski filozof niespełna pół wieku później jest już przekonany o tym, że nie ma, by tak rzec, niewinnych sprawczo wypowiedzi - tylko normalnego powiedzenia czegoś - że wszelkie nasze komunikowanie jest czymś więcej, mianowicie jest jakąś czynnością, działaniem, aktywnością pojetyczna - by posłużyć się grecką kategorią, stosowaną przez Arendt - a więc pewną interwencją w rzeczywistość, zaprowadzaniem w niej jakiegoś ładu, który wyklucza inne alternatywne możliwości. Poetyczny (w sensie: produktywny) charakter władzy polega na politycznym konstruowaniu podmiotów - ich legitymizowaniu i delegitymizowaniu.

Spróbujmy sytuację odwrócić i zapytać, co dzieje się wtedy, gdy odrzucimy tak szerokie pojmowanie władzy, wraz z jej wymiarem produktywnym, i zredukujemy ją do wymiaru prawnego - jurydycznego. Otóż okazuje się, że patrząc na władzę w ten sposób, tracimy ją samą z pola widzenia - przestajemy dostrzegać to, co ją „otacza”, czyli środki i techniki, którymi się posługuje. Jesteśmy wtedy na dobrej drodze do tego, by twierdzić, że władza jako taka nie istnieje (Foucault, 1998b, s. 183), a co za tym idzie - nie istnieje też i polityka jako obszar oddziaływań, sporów i konfliktów interesów grupowych. Judith Butler - kontynuatorka teorii francuskiej - pisze wprost: „operacje polityczne z powodzeniem «znikają» z pola widzenia i nabierają znamion naturalności w analizach politycznych przyjmujących struktury jurydyczne za punkt wyjścia" (Butler, 2008, s. 45). Władza jurydyczna wytwarza to, co niby reprezentuje - w ten sposób legitymizuje istniejące relacje społeczne i broni ich, uznaje ich konieczność i na- 
turalność. Prawo tworzy wyobrażenie czegoś pierwotnego, nietkniętego ludzką ręką, co usprawiedliwia jego hegemoniczną rolę w państwie. Uprawomocnia i uwiarygodnia ono samo siebie i stanowiony przez siebie porządek społeczny. Nieuchronnie wchodzimy tu w problematykę, której zakres obejmuje między innymi zjawisko sądokracji - sytuacji, w której polityka demokratyczna przenosi się z parlamentów do sal sądowych, a same sądy stają się coraz bardziej niezależne od „państwa”, czyli od pozostałych dwóch władz - ustawodawczej i wykonawczej. Sprawa to wielorako złożona, wpływają na nią dziś różne czynniki, takie jak na przykład prawo i instytucje międzynarodowe, ideologia technokratyczna itd. Nie jest to tylko problem rządów PiS w Polsce od 2015 roku - borykają się z nim także inne państwa (zob. np. Guarnieri, Pederzoli, 2012).

Sądokracja to jednak nie jedyny efekt uboczny spojrzenia na władzę sprowadzonego do rządów prawa - proceduralistycznej koncepcji demokracji. Można odnieść wrażenie, że modelowo taka redukcja dokonuje się obecnie w liberalno-lewicowym projekcie politycznym. Krytyczna teoria polityki, operująca analizą dekonstrukcyjną, ujawnia, że obiektywne nauki społeczne - tutaj to tyle co oparte na metodologii badań scjentystycznych - i równie obiektywne i uniwersalne reguły poprawności politycznej, którymi operuje liberalna lewica, są w gruncie rzeczy elitarne i ekskluzywne - mają wspólne resentymentalne źródła. Przemawia przez nie cynizm, hipokryzja i arogancki moralizm. Wroga definiują za pomocą kategorii „populizmu”, którego semantyka zawiera elementy tego, co niedemokratyczne w bogatej semantyce tego zaprzeczenia: faszystowskie, nacjonalistyczne, niehumanitarne - dziś chętnie określane również jako homofobiczne. Operowanie tym prostym dychotomicznym przeciwstawieniem to jedna z form ekscesów racjonalności politycznej, której mechanizmy „otaczają” realny proces władzy we współczesnych demokracjach. Skutkuje ona wykluczeniami i niesprawiedliwościami społecznymi, za którymi kryje się władza kapitału. Tak przykładowo opisuje tę sytuację Fredric Jameson - jeden z teoretyków czuwających nad wymykającymi się spod kontroli mocami racjonalności politycznej:

Rozpowszechniony cynizm jest faktycznie jedynym sposobem charakteryzowania politycznej transparentności współczesnego lub postmodernistycznego społeczeństwa, w którym „oni wiedzą, co robią, a mimo to nadal to robią", w którym każdy jest marksistą i rozumie dynamikę i szkody, jakie wyrządza kapitalizm, nie odczuwając, że można coś z nimi zrobić (Jameson, 2016, s. 22).

Polityka jako obszar walki i konfliktów interesów nie istnieje - dodajmy: w medialnie wyprodukowanej wyobraźni społecznej - ponieważ skutecznie przesłania ją wszechwładza kapitału. Blokuje ona impulsy do zmiany społecznej - do żądań sprawiedliwości. Udaje się jej to dzięki zafałszowaniu uniwersalności, przekonaniu innych - silnie uwodzicielskim, obrazowym, medialnym - że egalitaryzm jest po stronie kapitału. I to wszystko z przymrużeniem oka - uwaga: do mechanizmu uwodzenia nie stosuje się zasada sprzeczności - w konwencji gry, 
w której wszyscy uczestnicy dobrze wiedzą, że egalitaryzm i transparentność są niemożliwe do spełnienia. Nie pozostaje im więc nic innego jak tylko udawać, że wszyscy są egalitarystami - w cytacie to marksiści: synonim ludzi prawych, oświeconych i postępowych - i po cichu akceptować ograniczenia i szkody - nic nie da się z nimi zrobić - jakie wyrządza kapitalizm nieoświeconym i niepostępowym. Na tym polega rozpowszechniony cynizm współczesnej liberalnej lewicy.

\section{Sprawiedliwość, czyli o utopijnych impulsach w teorii}

Proceduralne rozumienie sprawiedliwości stanowi barierę dla interesujących mnie w tym artykule krytycznych teoretyków polityki, którym zależy na reformowaniu i rozszerzaniu usankcjonowanego władzą pola tego, co polityczne - na włączaniu do niego coraz to innych zjawisk uznawanych dotąd za niepolityczne, dlatego też i... nierzeczywiste i niezrozumiałe. W gruncie rzeczy chodzi tu jednak nie tylko o profesjonalnych teoretyków polityki, lecz o każdego świadomego uczestnika życia publicznego. Przy założeniu, że nadal konsekwentnie trzymamy się programu badań dekonstrukcyjnych, wedle którego - przypomnę - „analiza stawiająca pod znakiem zapytania władzę - oraz «agonalny» związek pomiędzy nią a niezbywalną wolnością - należy do zadań nieodłącznych od naszego społecznego bytowania" (Foucault, 1998b, s. 189).

Wszyscy jesteśmy więc krytykami polityki, kiedy stawiamy pod znakiem zapytania władzę, ponieważ mamy ku temu swoje racje, które potrafimy sami przedstawić lub znajdziemy innych, bardziej czujnych, którzy to w naszym imieniu uczynią, zawsze w jakiś sposób narażając się tejże władzy. Między nią i nami zawsze zachodzi jakiś konflikt, jakieś zmagania, rywalizacje, próby obejścia ustanowionego przez nią prawa, podważenia, zmienienia go, wymknięcia się spod jego kontroli itd. Dlatego agonistyczna wizja władzy odrzuca statyczne pojęcie sprawiedliwości - jako przestrzegania zasad prawa, systemu norm i reguł zamkniętego na zmiany, nowe interpretacje i aktualizacje - na rzecz sprawiedliwości dynamicznej, a wraz z nią koncepcji demokracji radykalnej. Nie będę szczegółowo wyjaśniał tych pojęć - ich historii i interpretacji. W kontekście tych rozważań wystarczy powiedzieć, że ze sprawiedliwością dynamiczną mamy do czynienia wtedy, gdy jako niesprawiedliwe oceniamy same określone normy i reguły. Domagamy się wówczas nowego porządku, nowego zestawu norm i reguł, który zastąpi stary. Podważając aktualne zasady, uciekamy się do nowych wartości, związanych szczególnie z naszą wolnością i życiem. W nowoczesności dynamiczna sprawiedliwość stała się zjawiskiem codziennym - zauważa Ágnes Heller. Delegitymizacyjne i legitymizacyjne roszczenia zaczęly odgrywać pierwsze skrzypce w procesie rozwiązywania konfliktów. Jest to kruche dziedzictwo. Nowoczesna demokracja zdaje się - tłumaczy filozofka - stale znajdować w swej 
pierwszej eksperymentalnej fazie. Kruchość tego dziedzictwa polega na tym, że im bardziej sprawiedliwość staje się dynamiczna, tym bardziej staje się też ona oczywista i - niestety - tym szybciej przemienia się w niesprawiedliwość. Wczorajsza sprawiedliwość jest dzisiejszą niesprawiedliwością; dzisiejsza sprawiedliwość jest jutrzejszą niesprawiedliwością (Heller, 1990, s. 152-154). To właśnie te egzystencjalne napięcia między władzą a wolnością są nieodłączne od naszego społecznego bytowania.

Gdyby sprawiedliwe osądy i regulacje prawne można było wyartykułować raz na zawsze, gdyby zaistniała dokładna tożsamość ustawy i faktu, to trzeba byłoby to uczynić w „wysokokulturalnej” sztuce argumentacji i zamknąć drogę do sporu oraz walki o nowy porządek społeczny, stać się "marksistą” i zrozumieć, że nic w świecie nie da się już zmienić. Powoływać się przy tym na uniwersalne prawa rozwoju społecznego i gospodarczego i w rezultacie - oddalić się od samych ofiar niesprawiedliwości: kruchych, słabszych i upokorzonych. Ci ostatni żądają sprawiedliwości innej niż tylko proceduralna. Dla nich bardziej niż to, co daje się wyartykułować za pomocą abstrakcyjnych pojęć, liczy się to, co się przeżywa - poszanowanie tych innych, ich bliskość, której przeżycie poprzedza wszelką racjonalną i uniwersalną wiedzę. Chodzi o poszanowanie lub przeżywanie bliskości, konkretnych, Izajaszowych wdów i sierot, które stawiają opór tej wiedzy - represyjności i zniewoleniu, które ona ze sobą niesie. Wniosek: sprawiedliwość wiąże się więc nie tyle z poznaniem, ile z pragnieniem (Deleuze, Guattari, 2016, s. 190). Dlatego sprawiedliwości - poskromienia ciemięzcy - żąda się, a nie o nią prosi. W rezultacie może się ona realizować tylko zdarzeniowo, w enklawach, strefach cienia, poza światłem reflektorów racjonalnych rozumowań i kalkulacji. Posłuchajmy raz jeszcze czujnych teoretyków: „Ale to, co ważne politycznie, wydarza się zawsze gdzie indziej, w kuluarach kongresu czy za kulisami wiecu, gdzie zostają skonfrontowane problemy immanentne pragnieniu i władzy - rzeczywiste problemy «sprawiedliwości»" (Deleuze, Guattari, 2016, s. 191). To tylko poszczególność domaga się sprawiedliwości - stawienia oporu temu, co wystawiane jest na scenie: ustabilizowanym relacjom, porządkom narzuconym na przypadkowe zdarzenia i sytuacje. Sprawiedliwości nie daje się więc przedstawić $\mathrm{w}$ trybie logicznej argumentacji - formułowanej przez racjonalne, dialogujące podmioty. Ciągle kwestionowana nie daje się wystawić na scenie - parlamentu, sali sądowej, mediów - i stanąć wobec przeciwnego, stabilnego, niesprawiedliwego stronnictwa - nie pozwala, żeby o nią walczyć z równie stabilnego etycznego stanowiska.

Tożsamości polityczne są relacyjne, występują tylko w pewnym systemie różnic - od kogoś/czegoś zależą, na kogoś/coś wpływają itd. - i dlatego nie są w stanie ukonstytuować siebie raz na zawsze. Każdy dyskurs o nich jest w nieskończoność zaburzany i wywracany. Napięte relacje między uniwersalnym i partykularnym, ogółem i różnicą, można opisać na przykład tak oto: „to, co partykularne, zmierzając zawsze ku temu, co wyjątkowe, jest właśnie wyjąt- 
kiem, który kończy się stanowieniem Prawa, tego, co Uniwersalne; cały ogólny system przechyla się przez to i kołysze do góry nogami” (Jameson, 2016, s. 94). Co to znaczy dla teorii? To mianowicie, że teoretyzowanie jest niekończącym się procesem: jego każdorazowy finał, w postaci instytucjonalnie ustalonych praw, zespołów faktów i twierdzeń, jest początkiem podważania ich prawdziwości, a co za tym idzie - destabilizowania także istniejącego systemu urządzeń i praktyk instytucjonalnych. Dla praktyki politycznej - będącej swoją drogą zawsze jakąś formą ekspresji teorii - oznacza to natomiast bardziej podtrzymywanie otwartej przestrzeni dyssensu pośród różnorodnych grup społecznych, ich potrzeb i interesów, niż zamykanie jej przez konsensualne praktyki gwarantowane przez państwo w interesie władzy (Rancière, 2008, s. 134-135). Czujność teoretyka o której od pewnego czasu mówię - musiałaby tu zatem być postawą z pogranicza teorii i praktyki, bardziej wyrażającą się w trosce o otwartość kanałów sporu i konfliktu politycznego niż o ich domknięcie.

Nierozerwalny splot języka i działania, faktów i znaczeń oznacza dla teorii politycznej utratę jej neutralności, nieuchronność zaangażowania w konflikty społeczne - funkcjonowania jako medium i narzędzie ich wyrażania i doświadczania. Czuwanie nad ekscesami racjonalności politycznej w tym kontekście wyraża się z jednej strony w unikaniu wszystkiego, co jest utopijne - $\mathrm{w}$ sensie formy: wizji ogólnej, rewolucyjnych zmian, fundujących całe nowe społeczeństwo - oraz w demaskowaniu, łamaniu tabu, wszelkiej totalności, całości i doskonałości. Z drugiej strony natomiast musiałoby ono polegać na dopuszczaniu w to miejsce istotnie utopijnego pragnienia, żądania, które płynie z doświadczenia codziennego życia, z doznań upokorzenia, przemocy, ciała otoczonego przez mechanizmy władzy, niedającego się zuniwersalizować. Utopijne impulsy, o których tu mowa, mają swoje źródło w czymś niepolitycznym, dzięki czemu to, co polityczne - prawo, instytucje państwa - nie daje się zatrzymać, w sensie: raz na zawsze usprawiedliwić, zalegitymizować, ujednoznacznić, skategoryzować i sklasyfikować, wyrwać z kontekstu, uwolnić od konieczności dalszych uzasadnień, pytań i wyjaśnień. Teoretyczny rdzeń utopii zdekonstruowanej, czyli, mówiąc najogólniej, takiej, która nie totalizuje, zawarty jest w myśleniu będącym także pragnieniem, szczególnym typem zaangażowania właściwego postawie badawczej opartej na uznaniu i afirmacji faktu, że to, co polityczne, jest radykalnie nieokreślone, nierozstrzygalne, pozbawione ostatecznej podstawy. Sądzę, że to właśnie dzięki takiej postawie teoria polityki jest $w$ ruchu i stale ma dopiero nadejść.

\section{Literatura}

Albert, M. (1994). Kapitalizm kontra kapitalizm, przeł. H. Jankowska. Kraków: Signum, Wydawnictwo Znak. 
Arendt, H. (2000). Kondycja ludzka, przeł. A. Łagodzka. Warszawa: Aletheia.

Arystoteles (1983). Metafizyka, przeł. K. Leśniak. Warszawa: PWN.

Austin, J.L. (1993). Mówienie i poznawanie: rozprawy i wykłady filozoficzne, przeł.

B. Chwedeńczuk. Warszawa: Wydawnictwo Naukowe PWN.

Banasiak, B. (1993). „Na tropach dekonstrukcji”. W: B. Banasiak (red.). Jacques Derrida: Pismo filozofii. Kraków: Inter Esse.

Baudrillard, J. (2014). Zapomnieć Foucaulta, przeł. K.J. Jaksender. Kraków: Libron.

Burzyńska, A. (2006). Anty-teoria literatury. Kraków: Universitas.

Butler, J. (2008). Uwikłani w płeć. Feminizm i polityka tożsamości, przeł. K. Krasuska. Warszawa: Wydawnictwo Krytyki Politycznej.

Castells, M. (2013). Sieci oburzenia i nadziei. Ruchy społeczne w erze Internetu, przeł. O. Siara. Warszawa: Wydawnictwo Naukowe PWN.

Castoriadis, C. (2018). „Kontestacja '68. O ideach i intelektualistach”, przeł. W. Dłuski. Przegląd Polityczny, 148, s. 110-113.

Deleuze, G., Guattari, F. (2016). Kafka. Ku literaturze mniejszej, przeł. A.Z. Jaksender, K.M. Jaksender. Kraków: Eperons - Ostrogi.

Derrida, J. (1993). „Farmakon”, przeł. K. Matuszewski. W: B. Banasiak (red.). Jacques Derrida: Pismo filozofii. Kraków: Inter Esse.

Derrida, J. (1999). O gramatologii, przeł. B. Banasiak. Warszawa: Wydawnictwo KR. Derrida, J. (2014). Uniwersytet bezwarunkowy, przeł. K.M. Jaksender. Kraków: Libron. Dubuy, A. (2018). „Jak wyglądał Maj '68 we Francji?”. Rzeczpospolita, 10.05.2018, https:// www.rp.pl/Rzecz-o-historii/305109903-Jak-wygladal-maj-68-we-Francji.html (dostęp: 22.08.2019).

Foucault, M. (2002). Archeologia wiedzy, przeł. A. Siemek. Warszawa: De Agostini.

Foucault, M. (1998a). Nadzorować i karać. Narodziny więzienia, przeł. T. Komendant. Warszawa: Aletheia.

Foucault, M. (1998b). „Podmiot i władza”, przeł. J. Zychowicz. Lewą Noga, 9, s. 174-192. Foucault, M. (2000). „Techniki siebie”. W: tegoż. Filozofia, historia, polityka. Wybór pism, przeł. D. Leszczyński, L. Rasiński. Warszawa: Wydawnictwo Naukowe PWN.

Friedman, M. (1951). „Neo-Liberalism and its Prospects”. Farmand, 17 (February), https://miltonfriedman.hoover.org/friedman_images/Collections/2016c21/Farmand_02_17_1951.pdf (dostęp: 14.08.2019).

Friedman, M. (1975). „National Economic Planning”. Newsweek, 14.07.1975. Tekst na stronie: https://miltonfriedman.hoover.org/friedman_images/Collections/2016c21/ NW_07_14_1975.pdf (dostęp: 17.11.2019).

Friedman, M. (1982). „Free Markets and the Generals”. Newsweek, 25.01.1982. Tekst na stronie: https://miltonfriedman.hoover.org/friedman_images/Collections/2016c21/ NW_01_25_1982.pdf (dostęp: 28.07.2019).

Guarnieri, C., Pederzoli, P. (2012). The Power of Judges: A Comparative Study of Courts and Democracy. Oxford: Oxford University Press.

Heller, A. (1990). Can Modernity Survive? Berkeley: University of California Press.

Hmissi, V. (2005). „Posłowie. Prawda i kłamstwo (w) dekonstrukcji”. W: J. Derrida. Historia kłamstwa: prolegomena: wykład warszawski, przeł. V. Hmissi. Warszawa: IFiS PAN.

Hudzik, J.P. (2011), Prawda i teoria. Warszawa: Scholar. 
Hudzik, J.P. (2016). „Intelektualiści w sferze publicznej: konteksty niemieckie”. Studia Philosophica Wratislaviensia, 2, s. 7-36.

Hudzik, J.P. (2017). „Teoria polityki w ruchu”. W: J. Nocoń (red.). Zagadnienia teorii polityki. Gdańsk: Instytut Politologii Uniwersytetu Gdańskiego.

Jameson, F. (2016). „An American Utopia”. In: S. Žižek (ed.). An American Utopia: Dual Power and the Universal Army. London: Verso.

Karwat, M. (2018). „O niezbędnym dopełnieniu optyki kratycznej w naukach o polityce”. W: S. Sulowski (red.). Nauki o polityce 2.0. Kontrowersje i konfrontacje. Warszawa: Dom Wydawniczy Elipsa.

Kuhn, T.S. (1985). Dwa bieguny. Tradycja i nowatorstwo w badaniach naukowych, przeł. S. Amsterdamski. Warszawa: PIW.

Larrondo, N. (2016). „Concentration Camps and Torture Centers in Chile during Pinochet's Dictatorship, 1973-1990”. Digital Public Humanities, Spring 2016 Course, Brown University (Jim McGrath).

Lévi-Strauss, C. (1970). Antropologia strukturalna, przeł. K. Pomian. Warszawa: PIW.

Markowski, M.P. (2010). „Humanistyka po dekonstrukcji”. W: E. Domańska, M. Loby (red.). French Theory $w$ Polsce. Poznań: Wydawnictwo Poznańskie.

Mouffe, Ch. (2008). Polityczność, przeł. J. Erbel. Warszawa: Wydawnictwo Krytyki Politycznej.

Müller, J.-W. (2016). Przeciw demokracji. Idee polityczne XX wieku w Europie, przeł. J. Majmurek. Warszawa: Wydawnictwo Krytyki Politycznej.

Nietzsche, F. (1912). Niewczesne rozważania, przeł. L. Staff. Warszawa-Kraków: Nakład Jakuba Mortkowicza.

Nietzsche, F. (1993). „O prawdzie i kłamstwie w pozamoralnym sensie”. W: tegoż. Pisma pozostałe 1862-1875, przeł. B. Baran. Kraków: Inter Esse.

Rancière, J. (2008). Nienawiść do demokracji, przeł. M. Kropiwnicki. Warszawa: Książka i Prasa.

Rasiński, L. (red.). (2009). Język, dyskurs, społeczeństwo. Zwrot lingwistyczny w filozofii społecznej. Warszawa: Wydawnictwo Naukowe PWN.

Tourain, A. (2010). O socjologii, przeł. M. Warchała. Warszawa: Wydawnictwo Naukowe PWN.

\section{Streszczenie}

Celem artykułu jest odtworzenie myśli politycznej zawartej w teorii francuskiej, związanej z postmodernizmem, znanej jako poststrukturalizm lub dekonstrukcja. Miała ona odpowiedzieć między innymi na takie pytania jak: Skąd biorą się nierówności i niesprawiedliwości $\mathrm{w}$ demokracji? I jaki jest udział w ich tworzeniu wiedzy naukowej, powstającej w ramach państwowych instytucji takich jak uniwersytety? Na czym polega fenomen władzy i relacji podległości w sytuacji, gdy chodzi o wolnych ludzi w państwie, które ma stać na straży ich praw jako obywateli i ludzi w ogóle? Artykuł, poza uwagami wstępnymi, składa się z sześciu części. Pierwsza opisuje kontekst społeczno-polityczny, w którym pojawia się postmodernizm. Część druga dotyczy teorii francuskiej. Czym jest dekonstrukcyjna teoria polityki i na czym polega stosowana przez nią metoda badań - o tym traktuje część trzecia. Część czwarta zajmuje się przemocą i uwodzeniem jako formami władzy sprawowanej także przez samych jej teoretyków. O polityce i władzy zredukowanej do systemu prawnego opowiada część pią- 
ta. Część ostatnia, szósta, mówi o sprawiedliwości rozumianej jako utopijne impulsy w teorii - zawiera wnioski z dekonstrukcyjnej analizy polityki.

Słowa kluczowe: teoria francuska, dekonstrukcyjna teoria polityki, władza, przemoc, uwodzenie, sprawiedliwość 